\title{
Beta-adrenergic function in airways of healthy and asthmatic subjects
}

\author{
P I ERR G A Y RAR D ${ }^{1}$, JEA N OREHEK ${ }^{1}$, \\ CHARLES GRIMAUD ${ }^{2}$, and JACQUES CHARPIN ${ }^{1}$ \\ Clinique de Pneumophtisiologie, Hôpital Ste Marguerite and Laboratoire d'Exploration \\ Fonctionnelle Respiratoire, Hôpital Salvator 2,13274 Marseille Cedex 2, France
}

\begin{abstract}
Gayrard, P., Orehek, J., Grimaud, C., and Charpin, J. (1975). Thorax, 30, 657-662. Beta-adrenergic function in airways of healthy and asthmatic subjects. We measured the short-term effects of beta-adrenergic blockade with propranolol $(0.2 \mathrm{mg} / \mathrm{kg} \mathrm{iv})$, followed by stimulation with salbutamol (200 $\mu \mathrm{g}$ inhaled), on specific airway conductance (SGaw), heart rate, and systemic blood pressure (BP) in 11 healthy subjects, and 11 symptom-free asthmatics with normal lung function values.

Propranolol induced a significant bronchoconstrictor effect in both groups, stronger in asthmatics than in normals: mean SGaw decreased $34 \cdot 6 \pm 25 \%$ against $9 \cdot 4 \pm 9 \%$ $(P<0.01)$. Six of the 11 asthmatics exhibited a more pronounced bronchoconstriction than the most responsive healthy subject. Large individual variations were seen in both groups although they were greater in the asthmatics. A similar rise in SGaw was produced by salbutamol in both groups. The decrease of heart rate provoked by propranolol was similar in the two groups, averaging $18.6 \%$, with no further change after salbutamol. The blood pressure was slightly decreased by propranolol in both groups.

The results indicate that normal subjects have a weak and variable bronchodilator beta-adrenergic activity. In most asthmatics beta-adrenergic tone appeared more pronounced. The individual differences in response to propranolol observed in both groups suggest that asthmatic patients differ quantitatively rather than qualitatively from healthy subjects with respect to beta-adrenergic receptor function. There was no association between clinical findings and the degree of bronchomotor effect of propranolol in the patients with asthma. This study does not support the view that airways of asthmatic patients have a decreased beta-adrenergic receptor function.
\end{abstract}

The existence of a bronchodilator influence mediated by the beta-adrenergic receptors, and opposed to the bronchoconstrictor tone of vagal origin (Widdicombe and Sterling, 1970), is still controversial in normal man. Beta-adrenergic blockade with propranolol has been reported in the literature as producing $(a)$ no effect (Tattersfield, Leaver, and Pride, 1973); (b) no significant bronchoconstriction (Richardson and Sterling, 1969; Zaïd and Beall, 1969); or (c) significant bronchoconstriction with marked differences (McNeill and Ingram, 1966; Macdonald, Ingram, and McNeill, 1967; Simonsson et al., 1970; Stone, Sarkar, and Keltz, 1973). The bronchoconstrictor effect of propranolol in patients with asthma is undisputed, although following the work of
McNeill (1964) and others (Langer, 1967; Richardson and Sterling, 1969; Zaïd and Beall, 1969; Gayrard, Orehek, and Charpin, 1971 and 1972; Jones, 1972) there have been shown to be pronounced individual variations in reaction, overlapping those of normals (Macdonald et al., 1967). Furthermore, in most experiments the subject's initial lung function was abnormal. In these instances, the difference between the asthmatic and the normal group in bronchial reaction to betablockade might be attributable to abnormal initial values (Pride, 1973).

We have therefore reevaluated the bronchomotor and cardiovascular effects of propranolol in healthy subjects and in asthmatics with normal respiratory function. We also have tried to deter- 
mine to what extent induced beta-blockade can be reversed by subsequent beta-stimulation (salbutamol).

\section{METHODS}

SUBJECTS Eleven healthy subjects ( 8 male, 3 female, average age $\pm S D=32 \cdot 8 \pm 7 \cdot 2$ years) free from clinical and radiological evidence of pulmonary disease were studied. Eleven patients ( 7 male, 4 female, average age $\pm \mathrm{SD}=30 \cdot 8 \pm 14 \cdot 3$ years) with asthma (history of spontaneous attacks of dyspnoea with perceptible wheezing, occurring mostly at night) but without clinical and functional symptoms of airways obstruction at the time of examination, were selected. For this reason specific airways conductance (SGaw) had to be equal to or above the mean SGaw of the control group. A further requirement was abstinence from medication for at least 48 hours. Physical, functional, and clinical characteristics of the normal and asthmatic subjects are available from the authors on request.

MEASUREMENTS Specific conductance (SGaw) $\left(\mathrm{ml} \mathrm{sec} \mathrm{CmH}_{2}^{-1} \mathrm{O}^{-1}\right.$ litre ${ }^{-1}$ ) was measured by panting at a frequency of 2 cycles/sec, and a flow-rate of 1 litre/sec (Butler el al., 1960) with the subjects seated in a constant volume body-plethysmograph throughout the study. Simultaneous recordings of airways resistance and thoracic gas volume were made (Electronics for Medicine, DR 8 amplifier-recorder, White Plains, NY). The resistance of the apparatus $\left(0.4 \mathrm{cmH}_{2} \mathrm{O}\right.$ litre $\left.\mathrm{sec}^{-1}\right)$ was subtracted. SGaw was obtained by dividing the reciprocal of the airway resistance by the thoracic gas volume at which the measurement was made. Blood pressure (BP) was measured by sphygmomanometer, and pulse rate was counted at the radial artery before each SGaw measurement. Each examination started at $2.30 \mathrm{pm}$. After 5 minutes for temperature equilibration, control measurements were made. Next, propranolol (Avlocardyl, ICI Pharma-France, $1 \mathrm{mg} / \mathrm{ml}, 0.2 \mathrm{mg} / \mathrm{kg}$ ) was injected into a forearm vein, in approximately $20 \mathrm{sec}$. SGaw, BP, and pulse rate were measured 5 and 10 minutes later. Following this, two puffs of salbutamol (Ventolin, Glaxo metered aerosol: $100 \mu \mathrm{g}$ per puff) were inhaled. The subjects were trained to inhale the aerosol, and then to hold their breath for 5 seconds, in order to obtain maximal particle retention. The nature of the investigation and the possibility of causing temporary aggravation of their condition had previously been explained to the subjects, all of whom were informed $\stackrel{\text { ज }}{\frac{F}{0}}$ volunteers.

Each SGaw value represents an average of three $\frac{\overline{\bar{c}}}{\overline{0}}$ to four measurements. Statistical analysis of the data was made by the $t$ test for paired variables. Each subject served as his own control. The ${ }^{\text {s }}$ difference between two means was considered not $\overrightarrow{0}$ significant (NS) if the $\mathbf{P}$ value was larger than $\overrightarrow{\vec{\omega}}$ $5 \%$.

In order to exclude the possibility of a placebo $\vec{F}$ response three further normal subjects and five $\vec{x}$ asthmatics were subjected to the same tests. following injections of saline and propranolol.

\section{RESULTS}

CONTROL GROUP (HEALTHY SUBJECTS)

Effects on airways After saline, the three normald subjects showed no change in SGaw. After pro- $₫$ pranolol, 10 of the 11 subjects had a decrease in? SGaw, with individual variations (Fig. 1). In six $\stackrel{\mathbb{Q}}{-}$ of these 10 the decrease in SGaw was more $\overrightarrow{0}$ pronounced at the fifth than at the tenth minute or after injection. Mean decrease of SGaw (Table I) was $9 \cdot 4 \% \quad\left(16.3 \mathrm{ml} \mathrm{sec} \mathrm{cmH}_{2} \mathrm{O}^{-1}\right.$ litre $^{-1} \pm 16 ;$

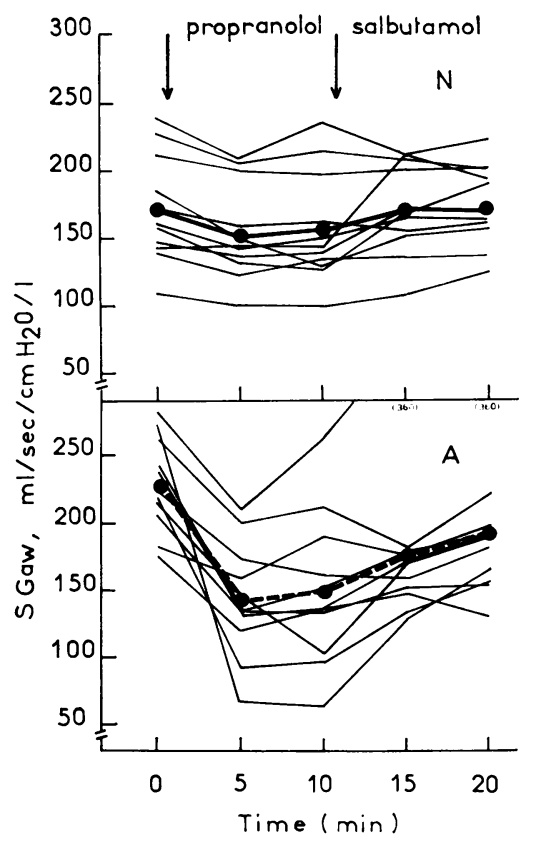

FIG. 1. Effects of propranolol $(0.2 \mathrm{mg} / \mathrm{kg}$ iv), and salbutamol $(200 \mu \mathrm{g}$, inhaled), on specific airwayo conductance (SGaw) in 11 normal subjects $(N)$, and $\overrightarrow{\mathbb{\Phi}}$ 11 asthmatics $(A)$. Individual values, and mean values (dots). 
T A B L E I

EFFECTS OF BETA-ADRENERGIC INHIBITION (PROPRANOLOL) AND STIMULATION (SALBUTAMOL) ON SPECIFIC AIRWAYS CONDUCTANCE (SGaw), PULSE RATE, AND BLOOD PRESSURE

\begin{tabular}{|c|c|c|c|c|}
\hline & & \multirow{2}{*}{ Control } & Propranolol & Salbutamol \\
\hline & & & $5 \mathrm{~min}$ & $10 \min$ \\
\hline $\begin{array}{l}\text { SGaw } \\
\left(\mathrm{ml} \mathrm{sec}-1 \mathrm{cmH}_{2} \mathrm{O}^{-1} l^{-1}\right)\end{array}$ & $\begin{array}{l}\mathbf{N} \\
\mathbf{A}\end{array}$ & $\begin{array}{r}174 \cdot 1 \\
\pm \quad 40 \cdot 1 \\
229 \cdot 2 \\
\pm \quad 35 \cdot 0\end{array}$ & 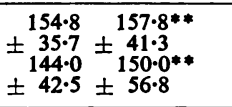 & $\begin{array}{l}172 \cdot 4 \quad 173 \cdot 6^{*} \\
\pm 31 \cdot 5 \pm 30.0 \\
179 \cdot 8 \text { 194.9**** } \\
\pm 63.2 \pm 61.6\end{array}$ \\
\hline Pulse rate (per min) & $\begin{array}{l}\mathbf{N} \\
\mathbf{A}\end{array}$ & $\begin{array}{r}73 \cdot 0 \\
+\quad 9 \cdot 3 \\
86 \cdot 8 \\
\pm \quad 14 \cdot 6\end{array}$ & 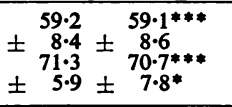 & 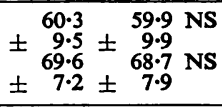 \\
\hline BP systolic (mmHg) & $\begin{array}{l}\mathbf{N} \\
\mathbf{A}\end{array}$ & $\begin{array}{r}125 \cdot 1 \\
\pm \quad 7 \cdot 3 \\
121 \cdot 8 \\
\pm \quad 12 \cdot 7 \\
\end{array}$ & $\begin{array}{l}119 \cdot 0 \quad 115.4^{*} \\
\pm 11.1 \pm 9.6 \\
119.0 \quad 118.6 \mathrm{NS} \\
\pm 12.0 \pm 10.9 \\
\end{array}$ & $\begin{array}{r}115.4 \quad 115.0 \mathrm{NS} \\
\pm 12.5 \pm 11.1 \\
116.7 \\
\pm 116.3 \mathrm{NS} \\
\pm 12.9 \pm 14.1\end{array}$ \\
\hline BP diastolic $(\mathrm{mmHg})$ & $\begin{array}{l}\mathbf{N} \\
\mathbf{A}\end{array}$ & $\begin{array}{r}86 \cdot 8 \\
\pm \quad 7 \cdot 8 \\
89 \cdot 0 \\
\pm \quad 9 \cdot 1\end{array}$ & $\begin{array}{r}82.7 \\
\pm 10.0 \\
86.8 \\
86.0 \\
\pm 97.0 \\
9.0 \\
\end{array}$ & $\begin{array}{r}81 \cdot 3 \\
9.7 \\
85.0 \\
87.2 \\
\pm 7.7 \\
86.3\end{array}$ \\
\hline
\end{tabular}

Eleven healthy subjects (N) and 11 patients with asthma (A). Mean values \pm SD. Statistical significance of difference, 10 min after propranolol from control, and $10 \mathrm{~min}$ after salbutamol from $10 \mathrm{~min}$ after propranolol: $* \frac{1}{\mathrm{P}}<0.05, * * \mathrm{P}<0.01, * * * \mathrm{P}<0.001$.

$\mathbf{P}<0.01$ ). The largest decrease in SGaw observed amounted to $31 \%$ of the initial value, in the absence of significant increase in mean thoracic gas volume. Following salbutamol, SGaw rose in seven of the 11 subjects by an average of $10.0 \%$ $\left(15.8 \mathrm{ml} \mathrm{sec}^{-1} \mathrm{cmH}_{2} \mathrm{O}^{-1}\right.$ litre $\left.{ }^{-1} \pm 25\right)$. Thus the mean SGaw value at the end of the experiment was nearly the same as at the beginning. Baseline values and/or smoking history did not influence the change in SGaw after propranolol.

Effects on heart rate and blood pressure The mean heart rate of all subjects decreased by $19 \cdot 1 \%$ after propranolol (Fig. 2 and Table I), $(13.8 \pm 7$ beats/min; $\mathbf{P}<0.001)$. Heart rate was unchanged by subsequent administration of salbutamol. Mean systolic BP after propranolol was decreased by $9.7 \mathrm{mmHg}(\mathrm{P}<0.01)$, while diastolic BP did not change significantly. No change in BP occurred after salbutamol.

There was no relationship beteen the cardiovascular and bronchomotor effects of propranolol.

\section{ASTHMATIC GROUP}

Effects on airways Figure 1 shows that a bronchoconstriction, with individual variations, appears after propranolol in 10 of the 11 patients with asthma. In six of the 11, the fall in SGaw was more marked at the fifth than at the tenth minute after injection. The average fall in SGaw (Table I) was $34.6 \%(78.3 \mathrm{ml} \pm 59, \mathrm{P}<0.01)$. The largest decrease in SGaw observed was $76 \%$ of the initial value. No significant increase in mean thoracic gas volume was noted. After salbutamol

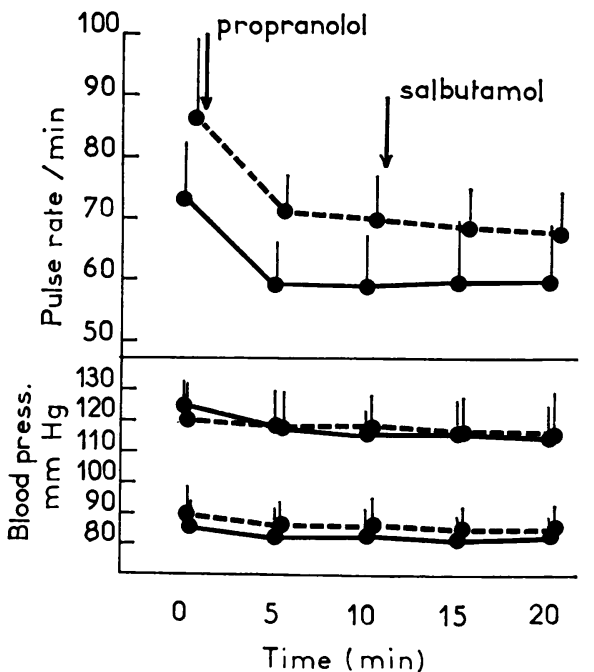

FIG. 2. Effects of propranolol $(0.2 \mathrm{mg} / \mathrm{kg}$ iv), and salbutamol $(200 \mu \mathrm{g}$, inhaled $)$, on pulse rate and blood pressure, in 11 normal subjects (-) and 11 asthmatics (-- -). Mean values \pm 1 SD.

SGaw rose in 10 of the 11 asthmatic patients, averaging $29.9 \%(44.8 \mathrm{ml} \pm 38, \mathrm{P}<0.01)$. The final value of SGaw remained lower than its initial value $-15 \%(36 \cdot 1 \mathrm{ml} \pm 51, \mathrm{P}<0.05)$.

There was no relationship between the initial value of SGaw and its alteration by propranolol. Also, no relationship between any single clinical feature (smoking history, severity or duration of the disease, skin test reactions) and the bronchial reaction to propranolol was noted. 
In order to detect a placebo-type response a placebo injection with saline was compared to the propranolol injection in an additional experiment. The patients, five asthmatics, all volunteers, did not know beforehand the sequence of experimental interventions. Initial SGaw was normal (mean value $196.0 \pm 16 \mathrm{ml}$ ). The saline injection produced a slight decrease in mean SGaw, $-3.7 \%$, as measured at the first minute. At the fifth and tenth minutes mean SGaw was not significantly different from the initial value. In contrast, the propranolol injection produced in the same subjects a decrease in mean SGaw: $31.5 \pm 7 \%(\mathrm{P}<0.02)$ at the fifth, and $29.8 \pm 6 \%$ $(\mathrm{P}<0.05)$ at the tenth minute (Table II).

Effects on heart rate and blood pressure $\mathrm{A}$ decrease in heart rate following propranolol occurred in 10 of the 11 patients with asthma: $18.6 \%(16.0 \pm 9$ beats $/ \mathrm{min}, \mathrm{P}<0.001)$, as shown in Figure 2. Heart rate was further decreased, slightly but not significantly, after salbutamol, averaging $-2 \cdot 0 \pm 4$ beats $/ \mathrm{min}$ (Table $\mathrm{I}$ ). We were unable to relate the cardiovascular and bronchomotor effects of propranolol. In the five further patients, heart rate was not influenced by saline but was decreased by propranolol $(-19.5 \%$; $\mathbf{P}<0.001$ ).

COMPARISONS BETWEEN GROUPS Figure 1 shows that the bronchomotor responses to propranolol and to salbutamol vary more widely between individuals in the asthmatic group than among the control subjects. The average bronchoconstrictor effect of propranolol is stronger in the asthmatic than in the control group $(P<0.01)$. Six of the 11 patients responded more than the most responsive normal subject. In contrast, the average bronchodilatation produced by salbutamol in the asthmatics was similar to that in the control subjects.

The initial mean heart rate was significantly $\frac{\bar{\sigma}}{\bar{c}}$ $(P<0.01)$ higher in the asthmatic group than in $\frac{\mathbb{D}}{D}$ the normal group although the decrease in heart $\stackrel{\circ}{\circ}$ rate after propranolol and salbutamol was similar is among the asthmatics and the control subjects. $\overrightarrow{0}$ Decrease in systolic and diastolic BP were not $\overrightarrow{-}$ significant.

\section{DISCUSSION}

The observed bronchoconstrictor effects of $\dot{\omega}$ propranolol support the opinion that there is, in o a majority of healthy subjects, a weak broncho- of dilator sympathetic tone at rest, analogous to that described in animals (Cabezas, Graf, and 음 Nadel, 1971). Diverging reports on the airway constrictor effects of the drug-induced betareceptor blockade in normal man appearing in $\varnothing_{\mathbb{\Phi}}$ the literature can be explained in part by difference in techniques and innate limitations of the $\mathbb{\Phi}$ methods. Maximal inspirations needed in some $\vec{\varphi}$ methods, as in FEV $_{1}$ and maximal flow-volume $v$ curves, decrease the effects of constrictor agents. in normal subjects (Nadel and Tierney, 1961). Voluntary panting remains the 'manoeuvre of choice' for estimating changes in resistance of intrathoracic airways (Mead, 1973). Hence we have compared our results only to other studies $\varrho$ using airway resistance measurements to assess $\overrightarrow{\overrightarrow{0}}$ changes in bronchial calibre. It must be kept in 3 mind that this resistance value is determined mostly by the diameter of the large airways.

A direct constrictor effect of propranolol on bronchial smooth muscle has been described in animals (Advenier, Boissier, and Giudicelli, 1972). However, in our experiment, as well as in others, the dose of drug used was less than that needed to obtain this effect. The antagonistic effect of $\stackrel{8}{2}$

T A B L E I I

EFFECTS OF INTRAVENOUS SALINE AND PROPRANOLOL INJECTIONS IN FIVE ASTHMATIC SUBJECTS

\begin{tabular}{|c|c|c|c|c|}
\hline & \multirow{2}{*}{$\begin{array}{l}\text { Initial } \\
\text { Values }\end{array}$} & \multicolumn{3}{|c|}{ After Saline-injection } \\
\hline & & $1 \mathrm{~min}$ & $5 \mathrm{~min}$ & $10 \mathrm{~min}$ \\
\hline \multirow[t]{3}{*}{$\begin{array}{l}\text { Mean SGaw } \pm \mathrm{SE}\left(\mathrm{ml} \mathrm{sec}-1 \mathrm{cmH}_{2} \mathrm{O}^{-1} \text { litre }^{-1}\right) \\
\text { Mean pulse rate } \pm \mathrm{SE}\left(\mathrm{min}^{-1}\right)\end{array}$} & $\begin{array}{r}196 \cdot 0 \\
7 \cdot 5 \\
90 \cdot 4 \\
7 \cdot 5\end{array}$ & $\begin{array}{l}188 \cdot 6 \\
6 \cdot 6 \\
88 \cdot 8 * * * \\
6 \cdot 4\end{array}$ & $\begin{array}{c}198 \cdot 2 \\
5 \cdot 6 \\
87 \cdot 2^{* *} \\
5 \cdot 2\end{array}$ & $\begin{array}{c}198 \cdot 0 \\
3 \cdot 7 \\
86 \cdot 0^{*} \\
4 \cdot 0\end{array}$ \\
\hline & \multirow{2}{*}{$\begin{array}{l}\text { Initial } \\
\text { Values }\end{array}$} & \multicolumn{3}{|c|}{ After Propranolol-injection } \\
\hline & & $1 \mathrm{~min}$ & $5 \mathrm{~min}$ & $10 \mathrm{~min}$ \\
\hline $\begin{array}{l}\text { Mean SGaw } \pm \mathrm{SE}\left(\mathrm{ml} \mathrm{sec}-1 \mathrm{cmH}_{2} \mathrm{O}^{-1} \mathrm{litre}^{-1}\right) \\
\text { Mean pulse rate } \pm \mathrm{SE}\left(\mathrm{min}^{-1}\right)\end{array}$ & $\begin{array}{r}198 \cdot 0 \\
3 \cdot 7 \\
86 \cdot 0 \\
4 \cdot 0\end{array}$ & $\begin{array}{l}143 \cdot 4 \\
9 \cdot 2 \\
69 \cdot 2 * * * * \\
3 \cdot 3\end{array}$ & $\begin{array}{l}135 \cdot 6 \\
15 \cdot 5 \\
69 \cdot 6 * * * * \\
4 \cdot 5\end{array}$ & $\begin{array}{l}138 \cdot 8 \\
14 \cdot 7 \\
70 \cdot 8 * * * * \\
5 \cdot 6\end{array}$ \\
\hline \multicolumn{5}{|c|}{ Paired comparisons of the differences were made by the $t$ test: ${ }^{*}=\mathrm{P}<0.05 ; * *=\mathrm{P}<0.02 ; * * *=\mathrm{P}<0.01 ; * * * *=\mathrm{P}<0.001$} \\
\hline
\end{tabular}


previous treatment with atropine, in both experimental animals and human subjects, demonstrated that the bronchoconstrictor influence unmasked by the beta-blockade was indeed that of the vagus (Herxheimer, 1967; Richardson and Sterling, 1969). Thus parasympathetic activity may largely account for the variations in the degree of bronchoconstriction after beta-blockade among the general population.

Although the half-life of the drug is more than two hours in man (Paterson et al., 1970; Tattersfield et al., 1973), we observed a rapid disappearance of the bronchomotor effect of the betablockade in our subjects, the maximum being close to 5 minutes after the injection. That this effect is only transient remains unexplained, and could be due to a spontaneous reduction in vagal tone. Such changes could have been missed in some other studies (Tattersfield et al., 1973).

In asthmatic subjects the mean bronchoconstrictor effect of propranolol was greater than in normal subjects, and could not be attributed to abnormal initial baseline values. In contrast to previous reports (Macdonald et al., 1967; Zaïd and Beall, 1969; Gayrard et al., 1971) we were unable to correlate significantly, in our group of patients in complete remission, the severity of the disease, established from the history, with the bronchial response to betablockade.

In some experiments (Langer, 1967; Grieco and Pierson, 1971; Zaïd and Beall, 1969) the use of tests needing forced respiratory movements may have artificially increased the bronchoconstrictor effect of propranolol (Gayrard et al., 1974).

The increased bronchoconstrictor effects of propranolol do not support the assumption of spontaneous 'partial beta-blockade' (Szentivanyi, 1968), at least for the majority of the subjects tested. Rather they suggest that, with few exceptions, either beta-adrenergic stimuli are more intensive or the beta-receptors are more sensitive in asthmatics than in normal subjects. Since the beta-adrenergic blockade effect on the heart rate was found to be similar in the two groups, this last hypothesis is not supported. Further, an adrenergic hyperactivity could account for the increased resting heart rate of the asthmatic group as compared to normals (Hahn, 1966).

The marked individual differences in response to beta-blockade cannot be attributed to abnormal initial values of airway resistance in patients with asthma. These differences suggest that asthmatic patients have a variable level of beta-stimulation. This could be explained either by variations of the stimulation from nerve endings and/or the adrenal medulla (Reinberg, Ghata, and Sidi, 1963), or by variations in receptor sensitivity to similar amounts of stimulants. The absence of individual correlation between changes in heart rate and bronchomotor effects induced by beta-blockade speaks against the last hypothesis. As in normal subjects, the unmasking of vagal bronchoconstrictor activity by propranolol has also been demonstrated in patients with asthma by the antagonistic effect of atropine (Langer, 1967; Macdonald et al., 1967; Grieco and Pierson, 1971; Gayrard et al., 1972). Again, individual differences in reaction to propranolol could be explained by differences in vagal activity between individuals (Simonsson, Jacobs, and Nadel, 1967).

The variability in responses to beta-blockade makes a comparison of average group results of little interest. The overlap observed between the bronchial effects of propanolol in normal subjects and asthmatics indicates that asthmatics differ quantitatively rather than qualitatively from normal subjects. As a practical consequence, it seems unwise to give propranolol for therapeutic purposes to the asthmatics, even those without symptoms.

The beta-adrenergic stimulant drug, salbutamol, produces the same bronchodilator effects after beta-blockade in both healthy and asthmatic subjects, although in the latter group the final mean value of SGaw was lower than the initial value because of the more marked bronchoconstrictor effect of propanolol. Thus, as expected, the agonist and antagonist seem to compete with one another for normal receptor bindings. The possible bronchoconstrictor effect of deep inspiration, while the patients inhaled salbutamol aerosol, would have tended to minimize the rise in SGaw. However, this effect would have decreased at the time of the SGaw measurement, 5 minutes later, and would be abolished by salbutamol (Gayrard et al., 1974).

This study was supported in part by a grant from the Institut National de la Santé et de la Recherche Médicale (INSERM).

The authors are grateful to Dr. Arend Bouhuys for help and advice in the preparation of the manuscript.

\section{REFERENCES}

Advenier, C.. Boissier, J. R., and Giudicelli, J. F. (1972). Comparative study of 6 beta-adrenoceptive antagonists on airway resistance and heart rate in the guinea-pig. British Journal of Pharmacology, 44, 642 . 
Butler, J., Caro, C. G., Alcala, R., and DuBois, A. B. (1960). Physiological factors affecting airway resistance in normal subjects and patients with obstructive respiratory disease. Journal of Clinical Investigation, 39, 584.

Cabezas, G. A., Graf, P. D., and Nadel, J. A. (1971). Sympathetic versus parasympathetic nervous regulation of airway in dogs. Journal of Applied Physiology, 31, 651.

Gayrard, P., Orehek, J., and Charpin, J. (1971). Le test au propranolol, nouveau test de provocation dans l'asthme. Etude comparative. Revue de la Tuberculose, 35, 511.

- - - , and (1972). Effets de differents produits bronchodilatateurs sur la conductance des voies aériennes dans l'asthme, lors d'un blocage beta-adrénergique provoqué. Bulletin de Physio-pathologie Respiratoire, 8, 625.

- , Grimaud, C., and Charpin, J. (1974). Effets bronchoconstricteurs de l'inspiration forcée dans l'asthme. Bulletin de Physiopathologie Respiratoire, 10, 79.

Grieco, M. H. and Pierson, R. N. (1971). Mechanism of broncho-constriction due to beta-adrenergic blockade. Journal of Allergy and Clinical Immunology, 48, 143.

Hahn, W. (1966). Autonomic responses in asthmatic children. Psychosomatic Medicine, 28, 323.

Herxheimer, H. (1967). The bronchoconstrictor action of propranolol aerosol in the guinea-pig. Journal of Physiology, 190, 41.

Jones, R. S. (1972). Significance of the effect of betablockade in ventilatory function in normal and asthmatic subjects. Thorax, 27, 572.

Langer, I. (1967). The bronchoconstrictor action of propranolol aerosol in asthmatic subjects. Journal of Physiology, 190, 41.

Macdonald, A. G., Ingram, Ch. G., and McNeill, R. S. (1967). The effect of propanolol on airway resistance. British Journal of Anaesthesia, 39, 919.

McNeill, R. S. (1964). Effect of a beta-adrenergic blocking agent, propranolol, on asthmatics. Lancet, 2, 1102.

- and Ingram, Ch. G. (1966). Effect of propranolol on ventilatory function. American Journal of Cardiology, 18, 473.

Mead, J. (1973). Pulmonary mechanics. Annual Review of Physiology, 35, 162.
Nadel, J. A. and Tierney, D. F. (1961). Effect of a previous deep inspiration on airway resistance in man. Journal of Applied Physiology, 16, 717.

Paterson, J. W., Connolly, M. E., Dollery, C. T., $\frac{\bar{s}}{J}$ Hayes, A., and Cooper, R. G. (1970). The $\mathbb{\Phi}$ pharmacodynamics and metabolism of propranolol in man. Pharmacologica Clinica, 2, के 127.

Pride, N. B. (1973). Bronchial sympathetic activity ? in chronic bronchitis. Clinical Science, 44, 517.

Reinberg, A., Ghata, J., and Sidi, E. (1963). Nocturnal asthma attacks: their relationship to $\vec{x}$ the circadian adrenal cycle. Journal of Allergy, 34, 323.

Richardson, P. S. and Sterling, G. M. (1969). Effects of beta-adrenergic receptor blockade on airway $\mathcal{G}$ conductance and lung volume in normal and asthmatic subjects. British Medical Journal, 3, 음 143.

Simonsson, B. G., Anderson, R., Bergh, B. E., Skoog, B. E., and Svedmyr, N. (1970). In vivo $\mathbb{}$ and in vitro studies of pharmacological effects $\mathbb{\Phi}$ on different receptors regulating bronchial tone $\frac{3}{\sigma}$ in man. In: Bronchitis III. Royal van Gorcum, Assen.

_- Jacobs, M., and Nadel, J. A. (1967). Role of $\vec{\vartheta}$ autonomic nervous system and the cough or reflex in the increased responsiveness of airways in patients with obstructive airways disease. Journal of Clinical Investigation, 46, 1812.

Stone, D. J., Sarkar, T. K., and Keltz, H. (1973). Effects of adrenergic stimulation and inhibition on human airways. Journal of Applied $\stackrel{\circ}{\varnothing}$ Physiology, 34, 624.

Tattersfield, A. E., Leaver, D. G., and Pride, N. B. (1973). Effects of beta-adrenergic blockade and stimulation on normal human airways. Journal of Applied Physiology, 35, 613.

Szentivanyi, A. (1968). The beta-adrenergic theory of the atopic abnormality in bronchial asthma. Journal of Allergy, 42, 203.

Widdicombe, J. G. and Sterling, G. M. (1970). The autonomic nervous system and breathing. Archives of Internal Medicine, 126, 311.

Zaïd, G. and Beall, G. N. (1969). Bronchial response to beta-adrenergic blockade. New England Journal of Medicine, 275, 580.

Requests for reprints to Dr. P. Gayrard, Hôpital Sainte Marguerite BP 29, 13274 Marseille Cedex 2, France. 